\title{
FEASIBILITY OF WOLF REINTRODUCTION TO NOVA SCOTIA: PUBLIC OPINIONS ON WOLVES AND THEIR MANAGEMENT IN LIGHT OF THE ECOLOGICAL POTENTIAL FOR WOLF RECOVERY
}

\author{
ANDREI N. WHITAKER ${ }^{1}$ AND KAREN F. BEAZLEY ${ }^{1}$
}

${ }^{I}$ School for Resource and Environmental Studies, Faculty of Management, Dalhousie University, 6100 University Ave., Halifax, NS, B3H 4R2

\begin{abstract}
This study investigated the ecological and social potential for wolf (Canis spp.) recovery in Nova Scotia, Canada. Reintroduction potential was considered through a GIS-based analysis of land cover, human population density, land ownership, prey density, and road density. Two disconnected areas of adequate habitat for wolves were identified. Qualitative interviews were conducted with seven identified groups on public attitudes towards the wolf and its potential recovery in the province. Opinions ranged from 'love' to a strong dislike of wolves, and many interviewees associated wolves with fear and expressed concern that they would come into contact with wolves on or near their properties. It would likely not be advisable to introduce an active wolf reintroduction program in NS at this time, due to the absence of effective habitat connectivity between the two identified areas of suitable habitat, and the public unease about wolf proximity. However, a proactive public education initiative is recommended in case of future reintroductions or natural immigrations of wolves and other top carnivores from nearby populations.
\end{abstract}

Key Words: Canis spp.; eastern wolf; rewilding; Maritime Provinces

\section{INTRODUCTION}

For the past few decades there has been growing interest in restoring wolves (Canis spp.) to portions of their historical range where sufficient habitat to maintain viable wolf populations exists (Fritts et al. 1995, Breitenmoser et al. 2001, Noss 2001, Nilsen et al. 2007, Licht et al. 2010). This has resulted in efforts in the United States which have allowed wolves to become re-established in some areas from which they were originally extirpated due to natural and humaninduced loss (Boyd et al. 1995, Fritts et al. 1995, Mech 1995, Bangs

* Author to whom correspondence should be addressed: karen.beazley@dal.ca. 
and Fritts 1996, Bangs et al. 1998, Parsons 1998, Paquet et al. 2001, Phillips et al. 2003).

While Canada does not have plans for wolf restoration to any of its provinces, wolf repopulations occurring in the northeastern United States would likely result in dispersal to and subsequently colonization of New Brunswick (Harrison and Chapin 1997, Harrison and Chapin 1998, Wydeven et al. 1998, Larivière et al. 2000, Carroll 2003, Carroll 2005). There is also the potential for wolf dispersal into New Brunswick from source populations in Québec (Harrison and Chapin 1997, Harrison and Chapin 1998, Carroll 2003). A wolf was shot and killed in New Brunswick in 2012, the first wild-origin wolf recorded in the province since 1862 and the second wolf to be found south of the St. Lawrence River since wolves were extirpated from the region (McAlpine et al. 2015). If wolves were to re-establish in New Brunswick, it is probable that they would disperse into Nova Scotia, as was the case with the eastern coyote ( $C$. latrans) (Moore and Parker 1992).

Wolves hold a powerful presence in the human psyche (Lopez 1978, Kellert 1986), resulting in strong and diverse public attitudes towards the animal (Nie 2001, Fritts et al.2003, Nie 2003). Wolf management and reestablishment are contentious issues (Bath and Buchanan 1987, Kellert et al. 1996, Mech 2000, Boitani 2003), typically polarized by heightened emotions (Hoffos 1987, Nie 2003). Even in areas where there is ample wolf habitat, people's attitudes still become an important variable in recovery decisions (Bath and Buchanan 1987), as human-caused mortality is one of the leading causes of death in wolf populations (Ballard et al. 1987, Tucker and Pletscher 1989, Forbes and Theberge 1996, Larivière et al.2000). While the attitudes of some Maritime residents towards wolves and wolf recovery have been explored (Lohr and Ballard 1996), and some public attitudes in Nova Scotia regarding predators have been examined (Marlin 2003, Weiss Reid 2003, Weiss Reid and Beazley 2004), no study specific to wolves in Nova Scotia has been undertaken. As the "success of [wolf] recovery efforts hinge, to a large degree, on the support and acceptance... by the public" (United States Fish and Wildlife Service 1987 p. 31), public attitudes are a crucial component of any reintroduction process (Thiel and Valen 1995).

Historically, the wolf species that inhabited eastern Canada and the northeastern United States was known as the eastern wolf (Canis lycaon), formerly the subspecies C.lupus lycaon (Nowak 1983, Nowak 
1995, Environment Canada 2015). The current taxonomic designation for eastern wolves is controversial due to hybridization with gray wolves (Canis lupus) and coyotes (Way et al. 2010, Wheeldon et al. 2010). While there was also some debate over even the existence of a Nova Scotian wolf population (Ganong 1908, Dodds et al. no date), a recent paper demonstrated historical evidence for a persistent wolf population in Nova Scotia up until the early $20^{\text {th }}$ century (Whitaker 2006, Whitaker and Beazley [in review]). In this study, we investigate the possibility of a future Nova Scotian wolf population from social and ecological standpoints. We first establish that there are ecological grounds for considering wolf reintroduction through a GIS habitat suitability model. As wolf populations in North America have been tied to public opinion for the last four centuries, our primary focus was qualitative research to explore attitudes and opinions that Nova Scotia residents have towards the wolf and its possible recovery in the province.

\section{METHODS}

\section{Determining potential habitat for wolves}

The development of a GIS habitat suitability model for wolves in Nova Scotia was based on five landscape criteria: land cover, human population density, land ownership, prey density (moose and deer), and road density (see Whitaker 2006 for model details). These variables characterize areas inhabited by viable wolf populations, and have been used to identify wolf habitat in northeastern United States (Harrison and Chapin 1997, Harrison and Chapin 1998, Mladenoff and Sickley 1998, Paquet et al. 2001). Two separate scenarios were considered, based on different thresholds of road density when determining suitable territory $\left(<0.45\right.$ or $\left.<0.6 \mathrm{~km} / \mathrm{km}^{2}\right)$ and dispersal corridors $\left(<0.7 \mathrm{~km} / \mathrm{km}^{2}\right.$ or no road density parameter). The model was created using ArcGIS 8.3 Spatial Analysis software (Environmental Systems Research Institute 2003). As population dynamics were not considered in the evaluation of habitat, the resulting model provides a static portrait of potential wolf habitat in Nova Scotia.

\section{Determining public perception of wolf reintroduction}

Person-to-person semi-structured qualitative interviews were conducted with respondents who fell into one of seven identified groups: hunters, farmers, environmentalists, wildlife managers, students, 
professionals, and retirees. Hunters, farmers, environmentalists, and wildlife managers were chosen as groups of individuals that may have strong preconceptions regarding wolves and their recovery/ reintroduction. Students, professionals, and retirees were targeted to ensure inclusion of diverse views and different age classes. Four participants from each category were interviewed, with the exception of the farmer group, wherein five people were interviewed.

Individuals were recruited using a 'snowball' technique, where initial contacts helped identify other relevant participants (Patton 1990, Babbie 1998, Merriam 2001, Warren 2001). A total of 29 participants were interviewed for 25 to 60 minutes. Interviewees were $38 \%$ female and $62 \%$ male; 8 interviewees lived in rural areas, while 19 lived in the Halifax area and two lived in other towns in the province.

Data analysis followed Creswell $(1994,1998)$ : (1) interview transcripts were read to obtain a sense of the data; ideas or reflections were noted; (2) each transcript was then carefully read and thoughts were recorded on the substance and themes of the interview; (3) themes were documented and clustered together, as transcripts were re-read; (4) themes were grouped into categories, and relationships between themes were explored; and, (5) narrative was written describing the themes and inter-relationships within and among them.

\section{Limitations}

The methods used in participant selection resulted in $65 \%$ of the interviewees being from the Halifax/Dartmouth area. Only 1/3 of the participants were from outside the province's major urban population and thus 'urban attitudes' could be overrepresented. The selection lacked gender equality, as male perspectives predominated, and cultural perspectives were not considered. In particular, the absence of First Nations people within this study was a strong limitation, as their cultural history provides evidence for the historical occurrence of wolves within the province and they would need to be consulted in any active reintroduction efforts.

\section{RESULTS}

\section{Habitat suitability model}

Only two areas of suitable habitat met the minimum size threshold required to support a viable population of wolves (Fig 1). In the 


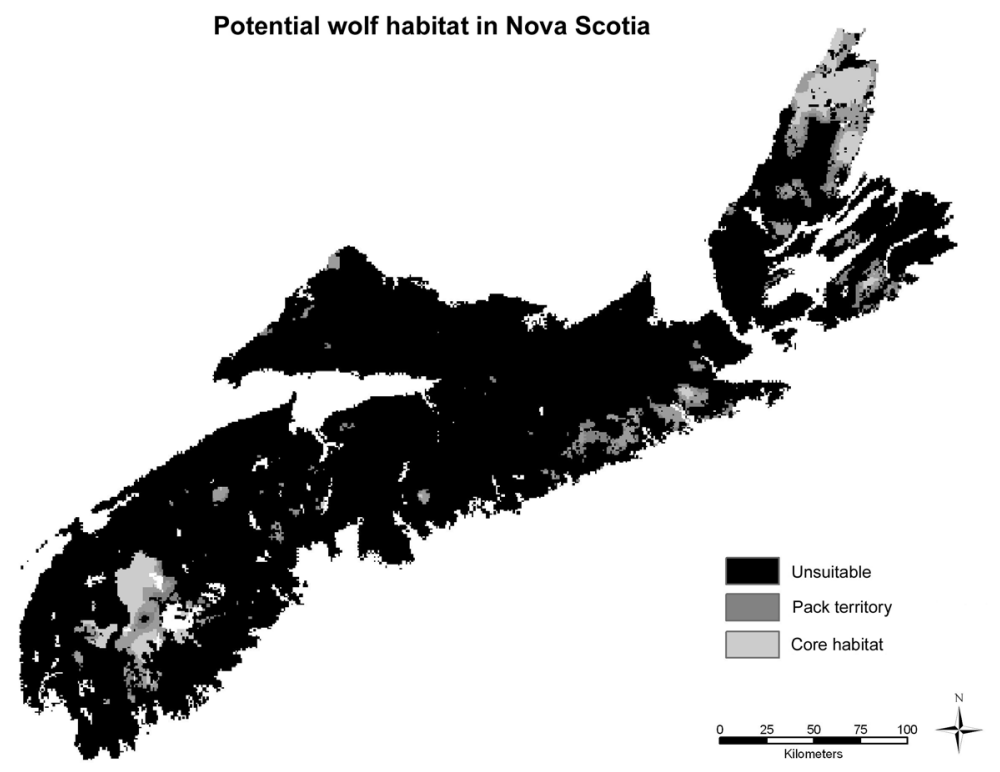

Fig 1 Map of potential wolf habitat (core and pack territory) in Nova Scotia. Both pack territory scenarios are shown in the darker grey.

northern end of the province, Cape Breton Highlands National Park and surrounding lands comprised $691 \mathrm{~km}^{2}$ of core habitat; in the south-west region, Kejimkujik National Park and National Historic Site, the Tobeatic Wilderness Area, and surrounding lands provided $458 \mathrm{~km}^{2}$ of core habitat. Supplementary habitat abutting these core habitat areas provided for a total of $1776 \mathrm{~km}^{2}$ of potential wolf habitat in the Cape Breton Highlands area, and $1155 \mathrm{~km}^{2}$ in the Kejimkujik region. Other areas of suitable quality of habitat were located across the province, but due to their small size and highly fragmented and isolated nature, they were not considered to be effective for wolf viability and thus not included.

With the two areas of suitable wolf habitat located at opposite ends of the province, the feasibility of habitat connectivity between them was considered in two scenarios. Following Harrison and Chapin (1997, 1998), two scenarios were run, modeling: (1) habitat suitability with a road density $<0.7 \mathrm{~km} / \mathrm{km}^{2}$; and (2) habitat suitability with the road density parameter removed (Fig 2). The first scenario identified extensive connectivity in the southern part of the province, but high 


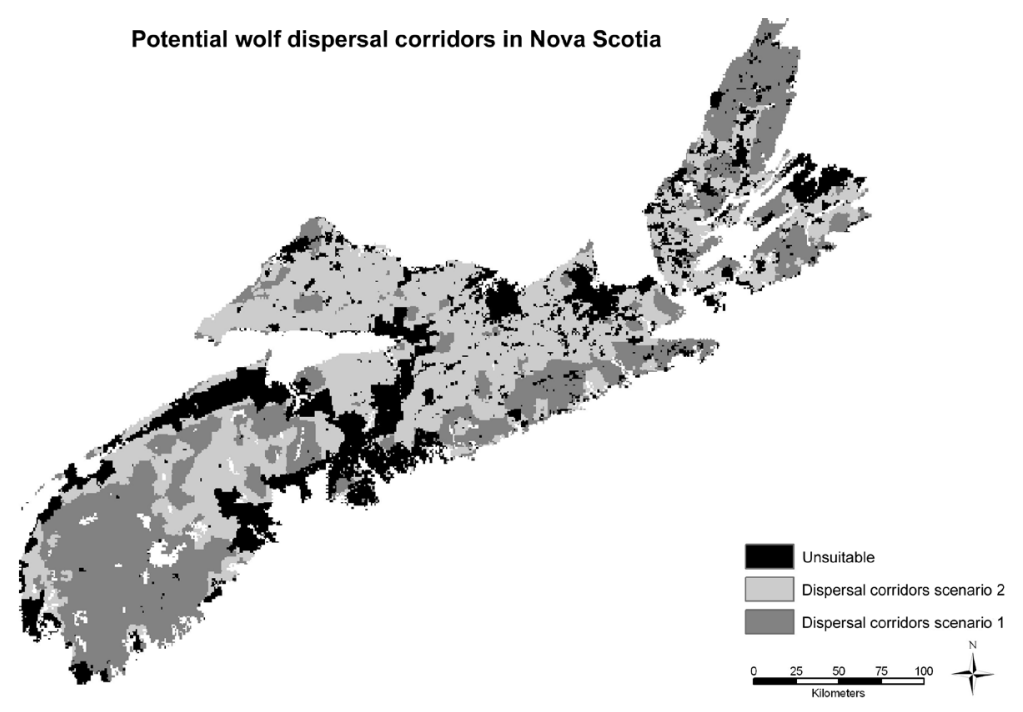

Fig 2 Map of potential wolf dispersal corridors in Nova Scotia.Darker grey dispersal corridor habitat includes road density restriction of $<0.70 \mathrm{~km} / \mathrm{km}^{2}$. Lighter grey connectivity habitat has no limit on road density.

levels of fragmentation beyond. The second analysis found Cape Breton Island and the upper mainland of the province to be highly connected, but revealed a potentially restrictive belt across the middle of mainland Nova Scotia, severing any possible sustained connectivity between the northern and southern areas.

In other reintroduction studies (Harrison and Chapin 1997, Harrison and Chapin 1998, Paquet et al. 1999, Paquet et al. 2001), the average wolf population density was determined to be from 1.0 to 4.0 wolves $/ 100 \mathrm{~km}^{2}$ based on wolf densities documented across North America by Ballard et al. (1987). Following this density approximation, the possible wolf population supportable in the Cape Breton Highlands and surrounding areas would be from 18 to 72 animals, while in Kejimkujik and the adjacent Tobeatic Wilderness Area, the population could range between 12 and 46 . Thus the total provincial wolf population would be 30 to 120 animals. This potential population size could be considered small; however, wolf populations are known to be self-sustaining with a total population size fluctuating between 40 to 120 individuals (Fritts and Carbyn 1995), and in the case of Isle Royale, fewer than 50 individuals (Boitani 2003). 
Carroll (2003) also identified areas of potential habitat for large carnivores such as wolves. In Nova Scotia, these were concentrated in the southwest and northeast portions of the province. Additionally, spatially-explicit population models predicted a potential for wolf re-colonization into Nova Scotia via Maine, New Brunswick and the Chignecto Isthmus (Carroll 2005). Thus, the successful reestablishment of wolves in the province would be largely related to social tolerance rather than habitat availability.

\section{Public perceptions of wolf recovery}

Participants displayed a broad range of opinions and attitudes towards wolves and their recovery in Nova Scotia (Table 1). At one end of the spectrum, respondents liked wolves and approved of the idea of wolf recovery, while on the other end, participants were averse to both the animal and its potential reestablishment. Despite the differences in opinions, three major themes emerged from the interviews: fascination and fear of the wolf, as well as questions concerning the wolf's physical ability to inhabit the province. These themes suggest that though many of the participants find wolves captivating on some level, attitudes around actual reestablishment are hesitant at best due to concerns over fear and limited space.

\section{DISCUSSION}

While this study found two suitable habitat areas for wolves in Nova Scotia, these regions are located at opposite ends of the province. Connectivity between them would be compromised by human activity and infrastructure. The shortest straight-line distance between Kejimkujik and the Cape Breton Highlands is approximately $450 \mathrm{~km}$, and during any dispersal wolves would have to contend with human barriers such as 4-lane highways and extensive farmlands. Wolves are capable of dispersing long distances, in some instances travelling over $800 \mathrm{~km}$ in a straight line from their original territory (Fritts 1983, Boyd et al.1995). However, dispersing wolves characteristically suffer from higher mortality rates than do resident pack members (Peterson et al. 1984), and in non-forested or high road-density areas, dispersing wolves are extremely vulnerable to human presence (Licht and Fritts 1994). Because of the perceived limited amount of wilderness, participants noted that the wolf may come into contact with humans or their property. Overall, the recognition that wolves could actually 


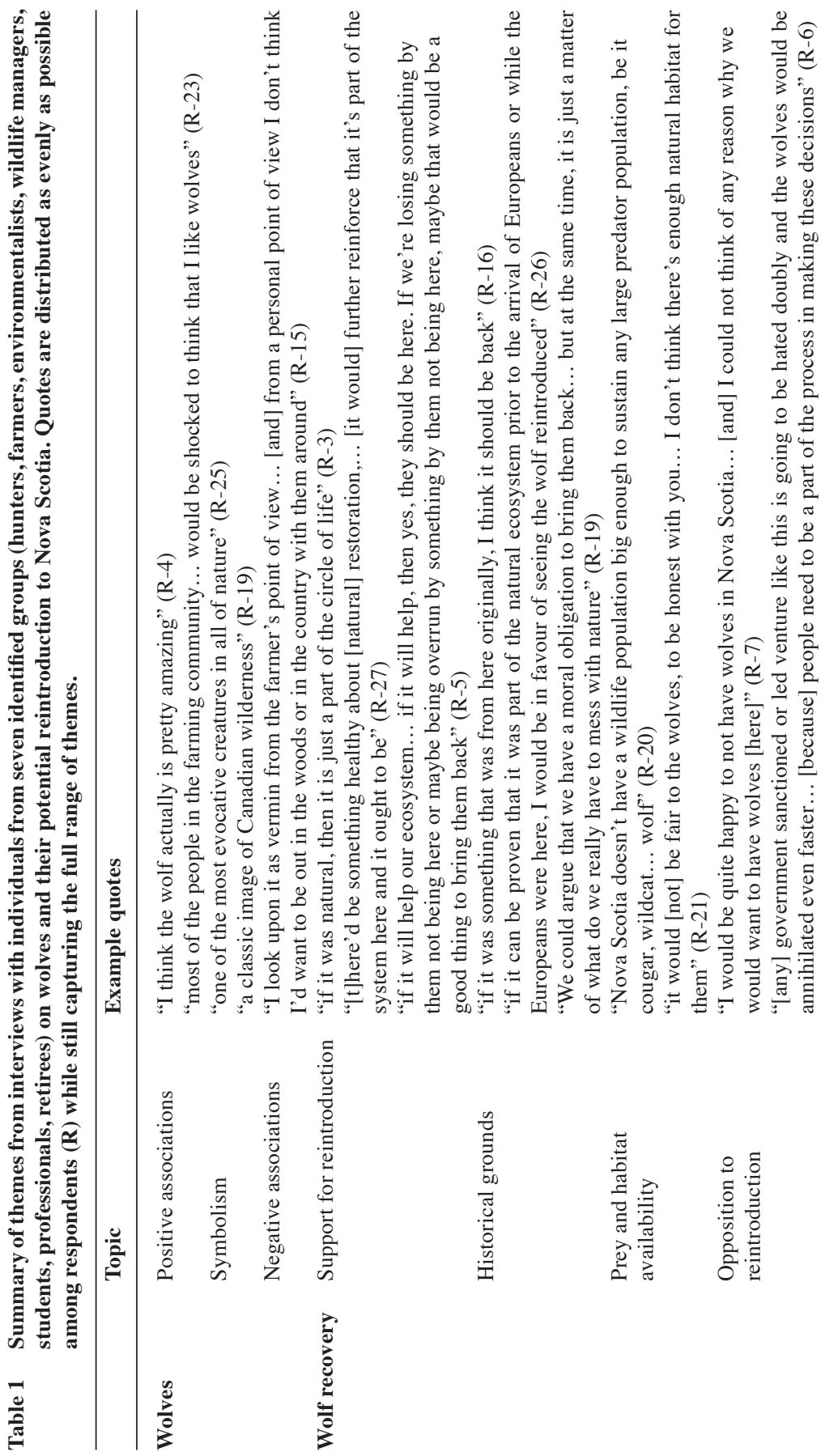




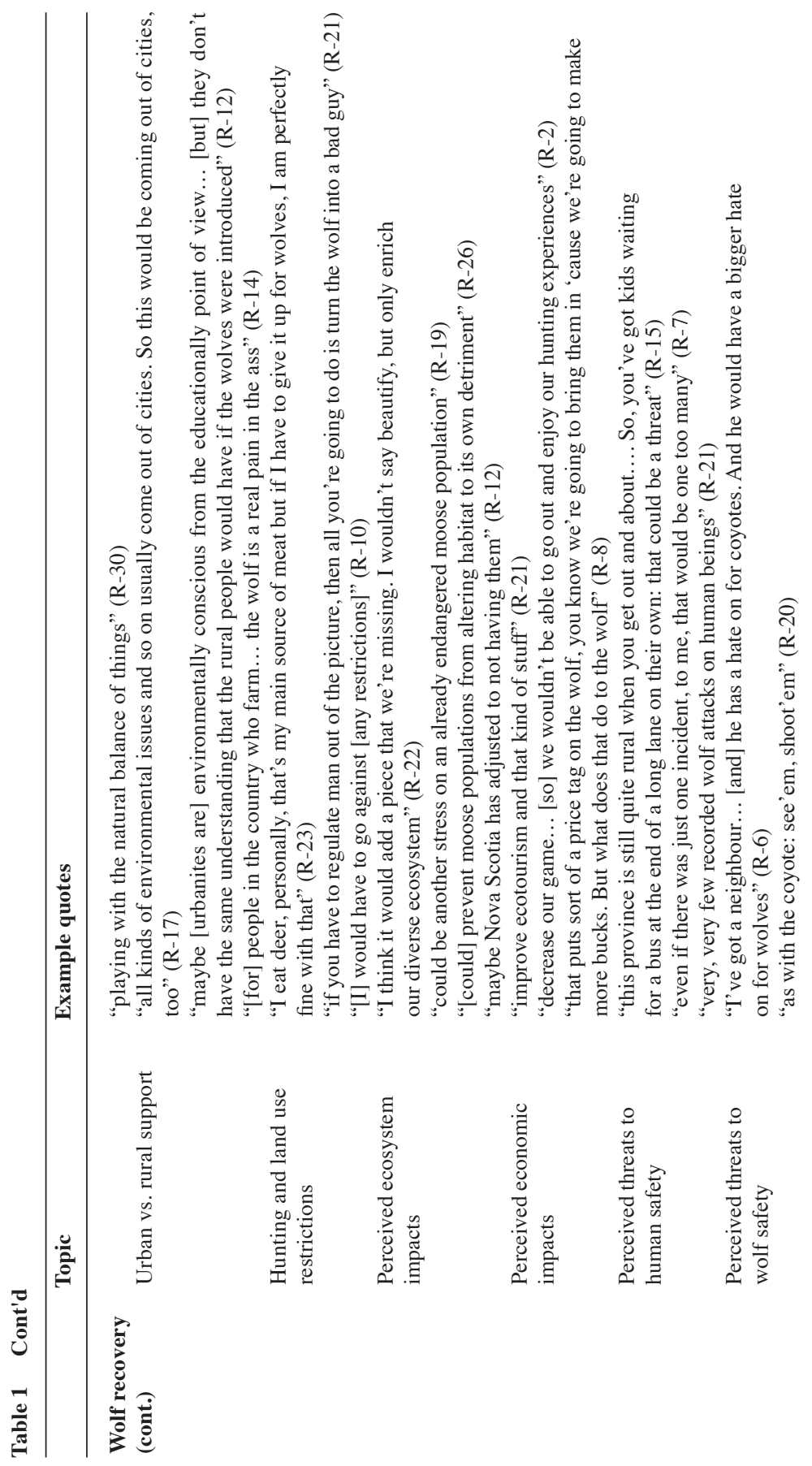




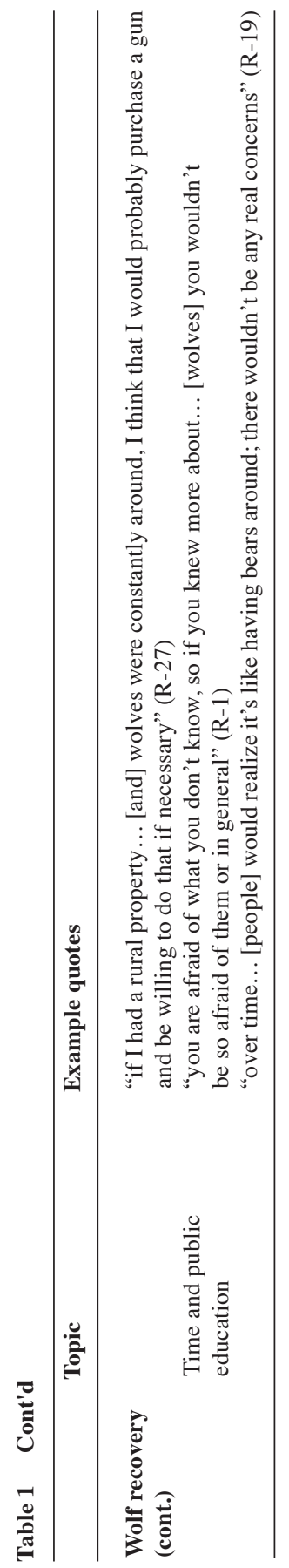


be near their homes made the participants cautious. "If they decided to take that part of land out there and put twenty wolves on it, I think I might not like that" (R-5), commented one respondent. Another participant observed that, "I would prefer to have them in an area not near my home... if that was a choice" (R-27).

In a study on public attitudes toward wildlife management, Reiter et al. (1999) found that one of the main concerns is a compromise of human safety by animals. This concern was echoed in a recent investigation into public attitudes towards wildlife in Nova Scotia, which found that many participants were fearful of the perceived threat to safety posed by the endemic predators of the province (Weiss Reid 2003, Weis Reid and Beazley 2004). Fear is considered to be a significant factor in motivating people to oppose wolf restoration (Hutt and Grooms 2000) and in impairing willingness to introduce wolves to an area (Lohr et al. 1996). Fear greatly contributes to a 'not in my backyard' (NIMBY) attitude (Edelstein 1988 in La Vine 1995), the characteristics of which many participants of this study unconsciously expressed in their concerns over safety. This fear could be a strong negative factor if restoration in Nova Scotia became a reality and would perhaps override, or at the very least conflict with, any positive attitudes the respondents were feeling.

As wolves move through semi-agricultural areas, conflicts with human interests become inevitable (Mech 1995). All of the participants in this study believed that wolves would be shot if they wandered onto private property. This stance is comparable to the findings in Weiss Reid (2003), where some participants believed that the rights of wildlife in Nova Scotia "were limited to wild or protected areas and not in human communities" (p. 125). As restoration in the province is contingent on wolves successfully dispersing hundreds of kilometres over private property, these results suggest that the current social context in Nova Scotia may not be favourable to wolf recovery. However, if given a degree of protection from persecution, it is possible that wolves would be able to persist in and disperse through a human disturbed landscape like Nova Scotia (Licht and Fritts 1994, Haight et al. 1998, Merrill and Mech 2000). Awareness and educational programs (as suggested by some respondents) could play an important initial part in any restoration program to discourage attitudes of fear and hostility towards the wolf (Kellert 1986, Kellert 1991). 


\section{Conclusion}

While wolves were undoubtedly once part of Nova Scotia's ecosystems (Whitaker 2006, Whitaker and Beazley [in review]), the landscape from which they were extirpated has changed. The once contiguous forested landscape has become a patchwork of civilization, and some of the formerly abundant prey species have disappeared or are in decline. Despite this environmental transformation, this study has shown that wolves could survive and possibly thrive in two core habitat areas that meet two fundamental requirements for a wolf population to exist: security cover/distance from humans and a sufficient prey base. These core habitat areas have the ability to support a small number of wolves, though without clear habitat connectivity between these core areas, the viability of these populations could be of concern.

As wolves were being extirpated in the early 1900 s, coyotes were expanding into the eastern portion of North America. Eastern coyotes have been abundant in the Maritime provinces since the 1960s (Forbes et al.2010). As they expanded their range, genetic introgression suggests there was interbreeding and hybridization between coyotes and eastern wolves (Rutledge et al.2010, Way et al.2010, Wheeldon et al. 2013). Some researchers have proposed renaming the current coyote in eastern North America a 'coywolf' to reflect its hybrid origin (Way et al.2010, Way 2013). Despite this genetic introgression, eastern wolves and coyotes remain morphologically, genotypically, and ecologically distinct (Benson et al. 2012, Wheeldon and Patterson 2012).

Wolf reintroduction efforts would be complicated by the difficulty in jointly or separately managing canid populations (Wheeldon and Patterson 2012), and by the potential for hybridization between any reintroduced wolves and coyotes. For that reason, some researchers have proposed using gray wolves from the Great Lakes area in eastern reintroduction plans, as there are no recorded hybridizations between the two canid groups (Way et al.2010, Wheeldon and Patterson 2012). Additionally, gray wolves are presumed to be sufficiently morphologically distinct to be almost always correctly differentiated by hunters in the field (Wheeldon and Patterson 2012).

While there are no existing plans to reintroduce the wolf to Nova Scotia, there is a small possibility that individuals could disperse from populations in Ontario and Québec, or from future reintroductions nearby (Carroll 2003,2005, McAlpine et al.2015). Nova Scotia could 
be proactive in devising a wolf management plan for the province based on this possibility. Public attitudes and opinions on wolves and their recovery within the province should be further explored, particularly among residents surrounding the two potential wolf core areas. Additionally, this study did not engage with the Mi'kmaq First Nation, though wolves are part of their cultural history and traditions. First Nations have the right to help determine the management of entities of spiritual and cultural significance, and may have unique perspectives on wolves and their restoration to the province. If wolf recovery seems imminent, the province could implement a public education program. If educational measures are initiated to help people understand wolf/large carnivore behaviour and how to react in human/large carnivore interactions, potential fears and conflicts could be avoided (Reading and Clark 1996).

Acknowledgements The authors would like to thank T. Nette, V. Power, C. McCarthy, and D. Quann for providing data on deer and moose population density within the province used in the Whitaker (2006) model, and B. Patterson and D. McAlpine for guidance on wolf-coyote hybridization. They would also like to thank S. Toni for helpful edits during the writing of this paper.

\section{LITERATURE CITED}

Babbie, E.R. (1998). The Practice of Social Research. Wadsworth Publishing, Belmont, California.

Ballard, W.B., Whitman, J.S., \& Gardner, C.L. (1987). Ecology of an exploited wolf population in south-central Alaska. Wildlife Monogr. 98:3-54.

Bangs, E.E., \& Fritts, S.H. (1996). Reintroducing the gray wolf to central Idaho and Yellowstone National Park. Wildlife Soc. B 24:402-413.

Bangs, E.E., Fritts, S.H., Fontaine, J.A., Smith, D.W., Murphy, K.M., Mack, C.M., \& Neimeyer, C.C. (1998). Status of gray wolf restoration in Montana, Idaho, and Wyoming. Wildlife Soc. B 26:785-798.

Bath, A.J., \& Buchanan, T. (1989). Attitudes of interest groups in Wyoming toward wolf restoration in Yellowstone National Park. Wildlife Soc B 17:519-525.

Benson, J.F., Patteron, B.R., \& Wheeldon, T.J. (2012). Spatial genetic and morphologic structure of wolves and coyotes in relation to environmental heterogeneity in a Canis hybrid zone. Mol. Ecol. 21:5934-5954.

Boitani, L. (2003). Wolf conservation and recovery. In: Mech, L.D., \& Boitani, L. (eds). Wolves: Behavior, Ecology, and Conservation. University of Chicago Press, Chicago, pp. 317-340. 
Boyd, D.K., Paquet, P.C., Donelon, S., Ream, R.R., Pletscher, D.H., \& White, C.C. (1995). Transboundary movements of a recolonizing wolf population in the Rocky Mountains. In: Carbyn, L.N., Fritts, S.H., \& Seip, D.R. (eds). Ecology and conservation of wolves in a changing world. Occasional Publication No 35. Canadian Circumpolar Institute, Edmonton, pp. 135-140.

Breitenmoser, U., Breitenmoser-Würsten, C., Carbyn, L.N., \& Funk, S.M. (2001). Assessment of carnivore reintroductions. In: Gittleman, S., Funk, S.M., Macdonald, D., \& Wayne, R.K. (eds). Carnivore Conservation. Cambridge University Press, Cambridge, pp. 214-281.

Cameron, A.W. (1958). Mammals of the islands in the Gulf of St. Lawrence. National Museum of Canada, Bulletin No. 154. Department of Northern Affairs and National Resources, Ottawa, ON.

Carbyn, L.N. (1983). Management of non-endangered wolf populations in Canada. Acta. Zool. Fennica 174:239-243.

Carbyn, L.N. (1987). Gray wolf and red wolf. In: Novak, M., Baker, J.A., Obbard, M.E., \& Malloch, B. (eds). Wild Furbearer Management and Conservation in North America. Ontario Ministry of Natural Resources, Toronto, pp. 358-377.

Carroll, C. (2003). Carnivore restoration in the northeastern U.S. and southeastern Canada: a regional scale analysis of habitat and population viability for wolf, lynx, and marten. Progress Report 1: Wolf viability analysis. Klamath Center for Conservation Research, Orleans, CA.

Carroll, C. (2005). Carnivore restoration in the northeastern U.S. and southeastern Canada: a regional-scale analysis of habitat and population viability for wolf, lynx, and marten. Report 2: Lynx and marten viability analysis. Wildlands Project Special Paper No.6. Wildlands Project, Richmond, VT.

Creswell, J.W. (1994). Research Design: Qualitative \& Quantitative Approaches. Sage Publications, London, UK.

Creswell, J.W. (1998). Qualitative Inquiry and Research Design: Choosing Among Five Traditions. Sage Publications, London, UK.

Dodds, D.F., Mullen, E., \& Martell, A. (n.d.). Notes on rare and extinct carnivora of Nova Scotia. Internal unpublished paper. Nova Scotia Department of Lands and Forests, Kentville, Nova Scotia.

Environment Canada. (2015). Eastern wolf. Species at Risk Public Registry. Environment Canada. Accessed 12 December 2015. www.registrelepsararegistry.gc.ca/species/speciesdetails_e.cfm?sid=608\#docs.

Environmental Systems Research Institute. (2003). ArcGIS. Release 8.3 [software]. Redlands, California.

Forbes, G.J., McAlpine, D.F., \& Scott, F.W. (2010). Mammals of the Atlantic Maritime Ecozone. In: McAlpine, D.F., \& Smith, I.M. (eds). Assessment of Species Diversity in the Atlantic Maritime Ecozone. NRC Research Press, Ottawa, pp. 693-718.

Forbes, G.J., \& Theberge, J.B. (1996). Cross-boundary management of Algonquin Park wolves. Conserv. Biol. 10:1091-1097.

Fritts, S.H. (1983). Record dispersal by a wolf from Minnesota. J. Mammal. 64:166-167. 
Fritts, S.H., Bangs, E.E., Fontaine, J.A., Brewster, W.G., \& Gore, J.F. (1995). Restoring wolves in the northern Rocky Mountains of the United States. In: Carbyn, L.N., Fritts, S.H., \& Seip, D.R. (eds). Ecology and conservation of wolves in a changing world. Occasional Publication No 35. Canadian Circumpolar Institute, Edmonton, AB, pp. 107-125.

Fritts, S.H., \& Carbyn, L.N. (1995). Population viability, nature reserves, and the outlook for gray wolf conservation in North America. Restor. Ecol. 3:26-38.

Fritts,S.H., Stephenson, R.O., Hayes, R.D., \& Boitani, L. (2003). Wolves and humans. In: Mech, L.D., \& Boitani, L. (eds). Wolves: Behavior, Ecology, and Conservation. University of Chicago Press, Chicago,pp. 289-316.

Ganong, W.F. (1908). On the occurrence of the wolf in New Brunswick. Bulletin of the Natural History Society of New Brunswick 26:30-35.

Gilpin, J.B. (1867). On the mammalia of Nova Scotia. In: Proceedings and Transactions of the Nova Scotian Institute of Natural Science for 1863, 1864, 1865, 1866, Volume I. James Bowes \& Songs, Halifax, Nova Scotia, pp. 8-15.

Haight, R.G., Mladenoff, D.J., \& Wydeven, A.P. (1998). Modeling disjunct gray wolf populations in semi-wild landscapes. Conserv. Biol. 12:879-888.

Harrison, D.J., \& Chapin, T.G. (1997). An assessment of potential habitat for eastern timber wolves in the northeastern United States and connectivity with occupied habitat in southeastern Canada. Working Paper No. 7. Wildlife Conservation Society, New York, NY.

Harrison, D.J., \& Chapin, T.G. (1998). Extent and connectivity of habitat for wolves in eastern North America. Wildlife Soc. B 26:767-775

Hayes, R.D., \& Gunson, J.R. (1995). Status and Management of Wolves in Canada. In: Carbyn, L.N., Fritts, S.H., \& Seip, D.R. (eds). Ecology and Conservation of Wolves in a Changing World. Occasional Publication No 35. Canadian Circumpolar Institute, Edmonton, AB, pp. 21-33.

Hoffos, R. (1987). Wolf management in British Columbia: the public controversy. Wildlife Bulletin No. B-52. Ministry of Environment and Parks, Victoria, British Columbia.

Hummel, M., \& Pettigrew, S. (1991). Wild Hunters: Predators in Peril. Key Porter Books, Toronto, ON.

Hutt, C., \& Grooms, S. (2000). What good is the wolf? Public opinion about wolves. International Wolf 10:5-8.

Kellert, S.R. (1986). The public and the timber wolf in Minnesota. T. N. Am. Wild. Nat. Res. 51:193-200.

Kellert, S.R. (1991). Public views of wolf restoration in Michigan. T. N. Am. Wild. Nat. Res. 56:152-161.

Kellert, S.R., Black, M., Rush, C.R., \& Bath, A.J. (1996). Human culture and large carnivore conservation in North America. Conserv. Biol. 10:977-990.

Larivière, S., Jolicoeur, H., \& Crête, M. (2000) Status and conservation of the gray wolf Canis lupus in wildlife reserves of Québec. Biol. Conserv. 94:143-151. 
La Vine, K.P. (1995). The attitudes of Utah residents toward gray wolves. MSc Thesis. Utah State University, Logan, Utah.

Licht, D.S., \& Fritts, S.H. (1994). Gray wolf (Canis lupus) occurrences in the Dakotas. Am. Midl. Nat. 132:74-81.

Licht, D.S., Millspaugh, J.J., Kunkel, K.E., Kochanny, C.O., \& Peterson, R.O. (2010). Using small populations of wolves for ecosystem restoration and stewardship. Bioscience 60:147-153.

Lohr, C., \& Ballard, W.B. (1996). Historical occurrence of wolves, Canis lupus, in the Maritime Provinces. Can. Field Nat. 110:607-610.

Lohr, C., Ballard, W.B., \& Bath, A. (1996). Attitudes toward gray wolf reintroduction to New Brunswick. Wildlife Soc. B 24:414-420.

Lopez, B. (1978). Of Wolves and Men. Charles Scribner's Sons, New York, NY.

Marlin, A.J. (2003). Exploring values and attitudes toward wildlife and conservation in central Nova Scotia: implications for biodiversity conservation. MES Thesis, Dalhousie University, Halifax, NS.

McAlpine, D.F.,Soto, D.X., Rutledge,L.Y., Wheeldon, T.J., White, B.N., Goltz, J.P., \& Kennedy, J. (2015). Recent occurrences of wild-origin wolves (Canis spp.) in Canada south of the St. Lawrence River revealed by stable isotope and genetic analysis. Can. Field Nat. 129:386-394.

Mech, L.D. (1995). The challenge and opportunity of recovering wolf populations. Conserv. Biol. 9:270-278.

Mech,L.D. (2000). Wolf restoration to the Adirondacks: the advantages and disadvantages of public participation in the decision. In: Sharpe, V.A., Norton, B.G., \& Donnelly, S. (eds). Wolves and Human Communities: Biology, Politics, and Ethics. Island Press, Washington, DC, pp. 13-22.

Merriam, S.B. (2001). Qualitative Research and Case Study Applications in Education. Jossey-Bass, San Francisco, CA.

Merrill, S.B., \& Mech, L.D. (2000). Details of extensive movements by Minnesota wolves (Canis lupus). Am. Midl. Nat. 144:428-433.

Mladenoff, D.F., \& Sickley, T.A. (1998). Assessing potential gray wolf restoration in the northeastern United States: a spatial prediction of favorable habitat and potential population levels. J. Wildlife Manage . 62:1-10.

Moore, G.D., \& Parker, G.R. (1992). Colonization by the eastern coyote (Canis latrans). In: Boer, A.H. (ed). Ecology and Management of the Eastern Coyotes. Wildlife Research United, University of New Brunswick, Fredericton, NB, pp. 23-37.

Nie, M.A. (2001). The sociopolitical dimensions of wolf management and restoration in the United States. Human Ecol. Rev. 8:1-12.

Nie, M.A. (2003). Beyond Wolves: The Politics of Wolf Recovery and Management. University of Minnesota Press, Minneapolis, MN.

Nilsen, E.B., Milner-Gulland, E.J., Schofield, L., Mysterud, A., Stenseth,N.C., \& Coulson, T. (2007). Wolf reintroduction to Scotland: public attitudes and consequences for red deer management. Roy. Soc. Lond. Proc. B Bio 274:995-1003.

Noss, R.F. (2001). Why restore large mammals? In: Maehr, D.S., Noss, R.F., \& Larkin, J.L. (eds). Large Mammal Restoration: Ecological and 
Sociological Challenges in the $21^{\text {st }}$ Century. Island Press, Washington, DC, pp. 1-21.

Nowak, R.M. (1983). A perspective on the taxonomy of wolves in North America.In: Carbyn, L.N.(ed). Wolves in Canada and Alaska: their status, biology, and management. Canadian Wildlife Service Report Series No 45. Environment Canada, Ottawa, pp. 10-19.

Nowak, R.M. (1995). Another look at wolf taxonomy. In: Carbyn, L.N., Fritts, S.H., \& Seip, D.R. (eds). Ecology and conservation of wolves in a changing world. Occasional Publication No 35. Canadian Circumpolar Institute, Edmonton, AB, pp. 375-398.

Parsons, D. (1998). "Green Fire" returns to the southwest: reintroduction of the Mexican wolf. Wildlife Soc. B 26:799-807.

Paquet, P.C., Strittholt, J.R., \& Staus, N.L. (1999). Wolf reintroduction feasibility in the Adirondack Park. Prepared for the Adirondack Citizens Advisory Committee on the Feasibility of Wolf Reintroduction. Conservation Biology Institute, Corvallis, OR.

Paquet, P.C., Strittholt, J.R., Staus, N.L., Wilson, P.J., Grewal, S., \& White,B.N.(2001). Feasibility of timber wolf reintroduction in Adirondack Park. In: Maehr, D.S., Noss, R.F., \& Larkin, J.L. (eds). Large Mammal Restoration: Ecological and Sociological Challenges in the $21^{\text {st }}$ Century. Island Press, Washington, DC, pp. 47-64.

Patton, M.Q. (1990). Qualitative Evaluation and Research Methods. Sage Publications, London, UK.

Peterson, R.O., Woolington, J.D., \& Bailey, T.N. (1984). Wolves of the Kenai Peninsula, Alaska. Wildl. Monogr. 88:3-52.

Phillips, M.K., Henry, V.G., \& Kelly, B.T. (2003). Restoration of the red wolf. In: Mech, L.D., \& Boitani, L. (eds). Wolves: Behavior, Ecology, and Conservation. University of Chicago Press, Chicago, IL, pp. 272-288.

Reading, R.P., \& Clark, T.W. (1996). Carnivore reintroductions: an interdisciplinary examination. In: Gittleman, J.L. (ed). Carnivore Behavior, Ecology, and Evolution: Volume two. Cornell University Press, Ithaca, NY, pp. 296-336.

Reiter, D.K., Brunson, M.W., \& Schmidt, R.H. (1999). Public attitudes toward wildlife damage management and policy. Wildlife Soc. B 27:746-758.

Rutledge, L.Y., Garroway, C.J., Loveless, K.M., \& Patterson, B.R. (2010). Genetic differentiation of eastern wolves in Algonquin Park despite bridging gene flow between coyotes and grey wolves. Heredity 105:520-531.

Sheldon, C. (1936). The mammals of Lake Kedgemakooge and vicinity, Nova Scotia. J. Mammal. 17:207-215.

Smith, R.W. (1940). The land mammals of Nova Scotia. Am. Midl. Nat. 24:213-241.

Thiel, R.P., \& Valen, T. (1995). Developing a state timber wolf recovery plan with public input: the Wisconsin experience. In: Carbyn, L.N., Fritts, S.H., \& Seip, D.R. (eds). Ecology and conservation of wolves in a changing world. Occasional Publication No 35. Canadian Circumpolar Institute, Edmonton, AB, pp. 169-175. 
Tucker, P., \& Pletscher, D.H. (1989). Attitudes of hunters and residents toward wolves in northwestern Montana. Wildlife Soc. B 17:509-514.

United States Fish and Wildlife Service. (1987). Northern Rocky Mountain Wolf Recovery Plan. United States Fish and Wildlife Service, Denver, CO.

Warren, C.A.B. (2001). Qualitative interviewing. In: Gubrium, J.F., \& Holstein, J.A. (eds). Handbook of Interview Research: Context and Method. Sage Publications, London, UK, pp. 83-101.

Way, J.F. (2013). Taxonomic implications of morphological and genetic differences in Northeastern Coyotes (Coywolves) (Canis latrans x $C$. lycaon), Western Coyotes (C. latrans), and Eastern Wolves (C. lycaon or C. lupus lycaon). Can. Field. Nat. 127:1-16.

Way, J.G., Rutledge, L.Y., Wheeldon, T.J., \& White, B.N. (2010). Genetic characterization of eastern "coyotes" in eastern Massachusetts. Northeast. Nat. 17:189-204.

Weiss Reid, J.E. (2003). Public preferences for wildlife species as a focus for biodiversity conservation in Nova Scotia. MES Thesis. Dalhousie University, Halifax, NS.

Weiss Reid, J. E., \& Beazley, K.F. (2004). Public preferences for wildlife as a focus for biodiversity conservation. In: Munro, N.W.P.,Herman, T.B., Beazley,K.F., \& Dearden,P.(eds). Making ecosystem-based management work. Proceedings of the Fifth International Conference of Science and the Management of Protected Areas, 11-16 May 2003. University of Victoria, Victoria, BC. Science and Management of Protected Areas Association, Wolfville, NS. <http://www.sampaa.org/publications.htm>.

Wheeldon, T.J., \& Patterson, B.R. (2012). Genetic and morphological differentiation of wolves (Canis lupus) and coyotes (Canis latrans) in northeastern Ontario. Can. J. Zool. 90:1221-1230.

Wheeldon, T.J., Patteron, B.R., \& White, B.N. (2010). Sympatric wolf and coyote populations of the western Great Lakes region are reproductively isolated. Mol. Ecol. 19:4428-4440.

Wheeldon, T.J., Rutledge, L.Y., Patterson, B.R., White, B.N., \& Wilson, P.J. (2013). Y-chromosome evidence supports asymmetric dog introgression into eastern coyotes. Ecol. Evol. 3:3005-3020.

Whitaker, A.N. (2006). A preliminary exploration of the ecological and social possibility of wolf recovery to Nova Scotia. MES Thesis. Dalhousie University, Halifax, NS.

Whitaker, A.N. \& Beazley, K.F. Evidence for the historical occurrence of wolves (Canis lupus) in Nova Scotia", in review.

Wydeven, A.P., Fuller, T.K., Weber, W., \& Macdonald, K. (1998). The potential for wolf recovery in the northeastern United States via dispersal from southeastern Canada. Wildlife Soc. B 26:776-784. 